\title{
THE TWENTIETH CENTURY DEVELOPMENT OF DIFFERENT TYPES OF BACTERIAL, BIOLOGICAL AND CHEMICAL WEAPONS AND THE PRESENT CAPABILITIES OF NATO AND THE WARSAW PACT IN THIS RESPECT
}

\author{
Capt A.L.S. Hudson*
}

\section{Introduction}

Over the last twenty years increased attention has been focused on the military uses of Bacterial, Biological and Chemical agents (BBC weapons). This phenomenon can be attributed to a number of reasons. Firstly, BBC weapons are comparatively cheap and simple to produce, they are easy to use as conventional weapons and their effects are short-lived. The mutual deterrence effect of nuclear weapons, furthermore, has necessitated the exploration of other fields of warfare of which - BBC warfare is a field. Another reason for this interest is the employment, on a limited scale, of such weapons in certain conflicts over this period.

The use of BBC weapons in warfare is almost as old as warfare itself. The poisoning of spears and arrows by ancient warriors can be regarded as a form of BBC warfare. In the Middle Ages it was common practice to catapult the bodies of diseased animals into a besieged city. These methods however were only employed sporadically and not as part of a co-ordinated strategy. It was not until the First World War (1914-1918) that a coherent strategy based on BBC weapons emerged.

\section{Aim}

The aim of this article is to review the different types of BBC weapons and protective measures developed during the twentieth century as well as the present offensive and defensive capabilities of NATO and the Warsaw Pact in this regard.

In order to approach this study in perspective, the subject will be reviewed within the following framework:

a. Clarification of concepts.

b. Development of the different types of BBC weapons.

c. Development of the different types of protective measures. d. Present offensive capabilities of NATO and the Warsaw Pact.

e Present defensive capabilities of NATO and the Warsaw Pact.

\section{Clarification of concepts}

IN order to prevent any misconception, it is necessary to determine the difference between bacteriological, biological and chemical weapons and to enlarge briefly on their characteristics.

a. Bacteriological weapons are various living organisms and bacteria (rickettsiae, viruses and fungi) used in the context of warfare with the intention of killing or incapacitating the enemy. ${ }^{(2: 5)}$

b. The term biological weapons is a collective name for all weapons of a biological nature (i.e. living organisms) that can be used in warfare. $^{(2: 5)}$ For the sake of clarity, therefore, the term biological weapons will be used throughout this study to a collective name for bacteriological and biological weapons.

c. Chemical weapons are toxic chemical substances, whether gaseous, liquid or solid, which can be employed in warfare in order to produce casualties either by incapacitation or death. ${ }^{(24: 3)}$

When comparing the characteristics of biologi$\mathrm{cal}$ and chemical weapons, it is found that chemical weapons are generally less potent on a weight-for-weight basis, produce injuries more rapidly, have a shorter life and a lesser degree of host specificity, are more controllable and have a lower risk of residual effects than biological weapons. ${ }^{(2: 6-9)}$

\section{Development of the different types of Biological weapons}

The development of biological weapons is diffi- 
cult to follow as one has to rely chiefly on allegations of the use of such weapons and reports of the possible possession of such weapons by a state. This difficulty in obtaining information can be ascribed to the secrecy with which such weapons are developed.

Biological warfare agents can be classified according to five groupings:

a. Micro-organisms (bacteria, viruses, rickettsiae, fungi and protozoa).

b. Vectors or carriers of disease (usually insects).

c. Toxins (poisonous chemicals devised from living organisms).

d. Pests of domestic and commercial plants and animals.

e. Some anti-crop agents or herbicides (eg worms). ${ }^{(11: 260-261)}$

During the First World War the German forces succeeded in isolating certain micro-organisms for military purposes. There is evidence that they were intended for use in covert action. The vectors were reported to have been domestic animals which were injected with the organism. ${ }^{(15: 65)}$ In 1931 Japanese interest in BW grew and by 1945 two factories had been erected for the production of bacterial toxins and vectors.

By the end of the war Japan had reached a stage where these weapons could be used offensively. Research and testing consisted of the production of weapons of sabotage for the purpose of exterminating animals and contaminating crops. Methods of dissemination included spraying from aircraft, bombing and direct contamination. ${ }^{(11: 55-56)}$ The other belligerents had no obvious BW ability but in the USA and Britain extensive research in this field was undertaken. ${ }^{(11: 68-139)}$

After 1945 there was a considerable increase in the development and use of BW weapons. Detail regarding this is not reliable as it consists mainly of allegations. As a result of these allegations it is evident that most biological weapons as they are known today were developed, isolated and tested in this period. ${ }^{(11: 299-308)}$ Development at present is so advanced that most major offensive conventional weapons have the ability to carry biological warheads. The most toxic agent to date is the organism Botulinum, a test tube of which could wipe out the population of Europe in a matter of hours. ${ }^{(10: 175)}$

\section{Development of the different types of chemical weapons}

The major known chemical weapons can be divided into the following groups:

a. Nerve agents.

b. Blister agents.

c. Choking agents.

d. Blood agents.

e. Toxins.

f. Fear and harassing gases.

g. Psycho-chemicals (for example LSD).

h. Certain herbicides.(2:12-13)

Contemporary chemical warfare began in 1914 with the use by the French of tear-gas artillery shells. These were followed by German attacks of chlorine gas in 1915. The next development was the use by the Germans of mustard gas and phosgene in 1917. The use of such weapons, however, led to the 1925 Geneva Protocols, outlawing the use of poison gases and other chemical and biological weapons. By 1944 Germany had succeeded in developing nerve gases (Tabun and Sarin). ${ }^{(11: 1-7)}$ Massive stockpiling of lethal agents and nerve gases was undertaken by the USA, UK and Germany during the Second World War but there is no evidence of the use of these weapons. The German factory that produced nerve gas during this period fell into Russian hands at the end of the war. ${ }^{(15: 65)}$ It is therefore presumed that the USSR has large quantities of nerve gas today.

Post-war development of chemical weapons was increased and encouraged by the growth in the number of revolutionary wars and the existence of nuclear deterrence. There is evidence that the Egyptians experimented with chemical weapons (mostly gas-bombs) in the war in Yemen in 1963. Chemical weapons (gases) were used by Egyptians and Syrians on a small scale during the SixDay War in 1967. ${ }^{(15: 65)}$ During the Vietnam War, the US forces made use of defoilants and herbicides to deprive the Vietcong of the natural cover of the vegetation of that state. ${ }^{(10: 177)}$ In the postwar years problems were experienced as regards the stockpiling and storage of chemical weapons. This, however, has been solved by the use of binary projectiles. The binary technique involves the separation of the constituents of a gas. These react together only during the trajectory of the projectile on its way to the target and produce the lethal gas..$^{(1: 21-27)}$ As is the case with biological weapons most present conventional weapons have the ability to use chemical warheads. 
It is interesting to take note of the most effective chemical warfare campaign in history, namely the Vietnam War. ${ }^{(18: 27)}$ The Vietcong exploited the unpopularity of the war and the low morale of the American Forces by the clandestine introduction of drugs to such an extent that this caused 10 percent of all American casualties in Vietnam. In 1971, for example, hard drug cases accounted for 7026 casualties alone. .(3:212) $^{2}$

\section{Development of protective measures}

Protective measures against BBC weapons cannot be seen in perspective without knowledge of the whole concept of counter-measures. Counter-measures involve the following:

a. Detection.

b. Physical and medical protection.

c. Decontamination. (2:19-25) $^{-2}$

For the purpose of this study a broad review of all the above will be undertaken.

Regarding biological weapons (as is the case to a lesser extent with chemical weapons) the best protection measure in the modern age seems to be the mutual deterrent effect that the possession of BW has on all forces involved. There is no evidence that systematic protection measures were introduced during the period discussed over and above the ability of man, through modern medicine, to isolate and utilise effective vaccines and the like against the outbreak of epidemics.

Since the first appearance of chemical weapons on the battlefield many methods have been used to develop effective protective measures. During the First World War, crude types of masks and helmets were used (as protection against gases) with varied results. ${ }^{(24: 5)}$ When mustard gas was used protection of the body became necessary. This problem was still unsolved at the end of the war. Between the First and the Second World Wars the effectiveness of masks and respirators was greatly enhanced and impregnated clothing and ointments were devised as protection against mustard gas. ${ }^{(24: 13-15)}$ Advances in the field of detection produced a paint, (used on vehicles and equipment) that changed colour in the presence of liquid agents. ${ }^{(14: 15)}$ This was supplemented by the development of a small detection kit used on the battlefield. ${ }^{(24: 29)}$

Since the appearance of nerve gases as a chemical weapon, various chemical and bio- chemical methods of detection have been developed. (24:39) At present four detection methods are used based on atmospheric particle-size analysis, flame spectrometry, the electrochemical properties of nerve gases and chemical reactions. ${ }^{(16: 66)}$ Protection devices in use at present, consist of masks fitted with an aerosol filter and a gas filter, various types of protective clothing, while armoured vehicles are fitted with air purifying systems. Decontamination plays an important role today and methods used range from personal decontamination kits to field stations with many facilities. The facilities offered by civil organisations are also utilised by the Swiss army for example.(16:66) Individual decontamination involves the use of bottles of oxidizing agents while the field and rear units offer far more advanced methods which incorporate changing rooms, showers, treatment rooms for the soldier as well as washing facilities for vehicles and equipment. ${ }^{(16: 66}$

\section{Present offensive ability of NATO and the Warsaw Pact}

Although both the USA and the USSR (and most of the states affiliated to NATO and the Warsaw pact) signed the Geneva Protocol of 1925 prohibiting the use in war of chemical and bacteriological weapons, this has not stopped these two organisations from developing and testing these weapons. The reasons given, for example, by the USA for continued development of such weapons is that the Geneva Protocol 'shall cease to be binding ... in regard to an enemy state if such state or any of its allies fails to respect the prohibitions laid down in the (Geneva) Proto-

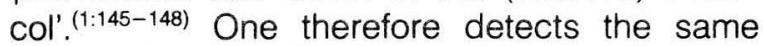
sense of mutual distrust here that is evident in the case of SALT I and SALT II. That the NATO and Warsaw Pact states therefore have an offensive ability as regards BBC warfare is a fact. A further Convention forbidding the development, production and stockpiling of bacteria for use as a weapon, the 1975 Biological Warfare Convention was signed by NATO and the Warsaw States as well. ${ }^{(8)}$ Of the NATO countries oniy France and the USA have CW stockpiles. ${ }^{(12: 35)}$ No information is available regarding French capabilities. A further issue that must be kept in mind in this regard is the fact that France is purely a 'sleeping partner' as regards NATO.

Offensively the Warsaw Pact (whose doctrine is derived trom Soviet doctrine) has an overall advantage over NATO in the field of BBC warfare. 
Chemical and Biological warfare is a standard part of their offensive doctrine. This is not the case as regards NATO despite the recent increased emphasis placed on BBC warfare by NATO commanders.

According to US intelligence estimates Soviet CW stockpiles outnumber those possessed by the US by 8 to 1 . As regards specialized $\mathrm{CW}$ personnel, the USSR has a 35 to 11 advantage and for CW delivery systems the ratio is 5 to 1 in favour of the USSR. ${ }^{(6: 14)}$ Furthermore ... 'The Soviets have the world's most fully trained and equipped chemical warfare force, which is prepared to operate in a chemical bacteriological and radiological environment. ${ }^{\prime(6: 14)}$ There are chemical warheads for mortars, field guns, multiple rocket launchers (MRL) and aircraft bombs. $30 \%$ of the FROG rocket and 'Scud' missile warheads and approximately $20 \%$ of all artillery munitions are chemical. ${ }^{(13: 25)} \mathrm{A}$ detailed table of the Soviet's Chemical delivery means can be seen in Appendix G.

An example of Soviet capability is the use of the major delivery system, the $122 \mathrm{~mm}$ BM-21 MRL (known to South Africans as the Stalin-organ). This weapon can fire 40 chemical rounds in 10 seconds, blanketing an area the front breadth and depth of an infantry company with $200 \mathrm{Kg}$ of toxic agents. ${ }^{(13: 25)}$ The Soviet division has 18 such MRLs enabling it to fire 720 rounds in $40 \mathrm{sec}$ onds. This ability is sustained by the longer range weapons with ranges of up to 280 kilometres. ${ }^{(13: 25)}$ An estimated 14 plants or factories are producing enough $\mathrm{CW}$ weapons to equip the Soviet Army to fight a CW war with NATO for 30 days to a depth of 500 kilometres. ${ }^{(6: 15)}$

It is interesting to note that only lethal agents are incorporated in the Warsaw Pact strategy and such agents as defoilants and hallucinatory incapacitants are disregarded in the event of a major war. ${ }^{(12: 31)}$ Another interesting estimate is that the Soviet chemical-warfare contingent regarding personnel amounts to $10 \%$ of its army.

No reliable information is available regarding the Warsaw Pact BW weapons. The world-wide publicity given to a disastrous accident in April 1979 at a secret germ-warfare factory in Sverdlovsk ( $1600 \mathrm{Km}$ east of Moscow), in which over 1000 people are believed to have died from anthrax, underlines the fact that the Warsaw Pact does possess a capability in this respect. ${ }^{(8)}$ Furthermore it is reported that during the Cuban
Missile Crisis of 1962 the Soviets had enough bacteriological weapons in underground tunnels in Cuba to exterminate the entire American population. ${ }^{(4)}$ This, however, has not been verified.

A comparison between US and USSR overall capabilites has already been shown. Further restrictions on NATO countries in this respect are the limited life-time of present US stockpiles. Estimates judge that US stocks will have become useless by the later 1980s and at present the USA has no useable production site..$^{(14: 3-4)}$ The US defence budgets from 1977 to 1980 have included no money for $\mathrm{CW}$. This is rationalised by congressmen and American generals by arguments that the mere possession of $\mathrm{CW}$ weapons is sufficient to deter their use. ${ }^{(14: 4)} \mathrm{A}$ further restriction on NATO as a whole is their policy of 'retaliation' rather than 'first strike ability'.

The US stockpiles contain approximately 3 million artillery projectiles, several thousand aerial bombs, chemical landmines and aircraft spray tanks as well as mustard gas dating from the Second World War. Total stocks of lethal chemical munitions amount to 150000 tons of which nerve gas constitutes two-thirds. On a weight basis this constitutes a quarter of the conventional munitons the US Army has on hand in Europe. (20:36)

Information regarding BW capabilities of NATO is limited. There is evidence, however, that the USA seriously considered breeding hundreds of millions of disease-carrying mosquitoes (the Aedes Egypt-sort) to infect enemy areas with yellow fever in time of war. This strain of mosquito would be particularly useful against Russia as it is rare in that area and Russian citizens would be less immune to it. ${ }^{(21)}$ Other alleged capabilities include the recent accusation of the US, by the Soviet news agency Tass, that the US is responsible for having caused a virus epidemic near Madred in Spain.

The agency claims that the source of an unknown strain of pneumonia (which has taken the lives of 18 people and hospitalised 1500), is a US military base near Madrid where BW weapons are stockpiled. ${ }^{(5)}$ This report, (although merely on allegation) is indicative of the deep suspicion with which NATO and the Warsaw Pact states regard each other. 


\section{Present defensive capabilities of NATO and the Warsaw Pact}

The Warsaw Pact states are generally more advanced as regards defensive and protective capabilities in BBC warfare. Their equipment may not be superior in quality but the training and integration of defensive capabilities is more comprehensive than in NATO.

The Soviets have built-in defence systems such as seals and filtered air supplies as well as alarm systems in their tanks, APC's and other fighting vehicles. This enables the occupants to operate without the restrictions imposed by the wearing of masks. It is further believed that Soviet aircraft and naval vessels have similar capabilities. ${ }^{(6: 14)}$ Today all Soviet troops are issued with effective protective clothing, personal-decontamination and countermeasure-medical kits and are constantly trained in their use. ${ }^{(12: 32)}$ The Russian Military Chemical Forces (VKhV), numbering between 80 and 100000 , are trained and equipped purely for chemical defence and are attached on all levels from Front down to regiment. ${ }^{(12: 32)}$ This organisation deals with chemical contamination which is too great for normal units to cope with. Other tasks include decontamination and reconnaissance. ${ }^{(12: 33)}$ Over and above the military defensive capability, the Soviets possess a 'civilian' voluntary organisation claiming a membership of 15 million dedicated to Nuclear, Biological and Chemical (NBC) defence, instruction and training. ${ }^{(12: 33)}$ Problems regarding training have been experienced as there seems to be a lack of a standard operational procedure for reacting to a chemical attack. Other problems include the vulnerability of Soviet troops to a surprise attack due to the fact that the protective clothing is not worn at all times. ${ }^{(12: 33)}$

Warsaw Pact states have a considerable decontamination ability. Use is made, in the case of vehicles, of the TMS-65 vehicle which has a turbo-jet mounted on a turntable which in turn is mounted on a truck. The unit tows a tank of decontamination chemicals which can be sprayed on contaminated vehicles as they pass. ${ }^{(7: 36)}$ This device can decontaminate 40 tanks or 60 trucks in an hour. (22:101)

NATO defence capabilities regarding BBC warfare constitute the most important part of this organisation's BBC capabilities. One of the fields in which NATO has a distinct advantage is personal protection of the soldier. The NATO models of gas masks can be donned in 10 seconds, can be worn for long periods and can be safely used while sleeping. The Russian mask is harder to don, heavier and less comfortable. ${ }^{(20: 37)}$ British and American models of protective clothing are able to 'breathe', enabling the soldiers to operate effectively for longer periods of time than their Warsaw pact counterparts. ${ }^{(20: 37)}$ New devices of detecting and identifying $\mathrm{BBC}$ agents dominate research in NATO. ${ }^{(17: 19)}$

Extensive time and effort has been put into training in BBC warfare defence. In Britain alone subunits of the Army, Marines and Air Force spend two 48-hour periods a month training in defensive measures. The Soviets however, make use of CW weapons (and not simulation) when training their soldiers. This stage of advancement has not yet been reached by NATO. (23:22)

Decontamination methods used by NATO are archiac compared to Warsaw pact states and lack the speed that the Soviets have achieved. The only NATO vehicles with built-in collective protection systems are the command and control vehicles. ${ }^{(6: 15)}$ This forces troops to use their personal equipment and contributes to fatigue as a result of heightened restrictions imposed on manoeuverability by the equipment. The USA has only 2200 troops whose duties include advising units on $\mathrm{CW}$ defensive measures. Added to this, the naval vessels are even further behind in $\mathrm{CW}$ protection, lacking a wetting down and sealing capability. ${ }^{(6: 15)}$

\section{Conclusion}

When reviewing the development of $\mathrm{BBC}$ weapons one is struck by their lethality and latent ability to cause massive losses of human life. In this review, however, the problems associated with isolation, dissemination, climate, control and security have not been discussed. These problems can lend a measure of perspective to the subject of $\mathrm{BBC}$ warfare in that they cause one to realise that successful use of BBC weapons depends on many factors and the employment of such weapons requires the same level of decision-making as is needed with the employment of nuclear weapons. Far from being the ultimate weapon the increased use of BBC weapons in the last two decades has underlined their importance in the context of indirect strategy.

It can furthermore be concluded that the level of preparedness, (offensive and defensive), of NATO in terms of organisation, equipment and training standards, is generally well below that of 
the Warsaw Pact. Added to this one must also bear in mind the two opposite perceptions as to the role that $\mathrm{BBC}$ weapons can play in a major war between these two organisations.

* The above contribution was the best entry received for the Service Paper contest of 1981

\section{Bibliography}

1. Anonymous: Chemical Disarmament: New Weapons for Old. A SIPRI Monograph. New York (etc), 1975.

2. Anonymous: Report of the Secretary-General on Chemical and Bacteriological (Biological) Weapons and the Effects of their Possible Use. New York, 1969.

3. Ronds, R.: The Vietnam War. London, 1979.

4. Die Burger, 8 April 1981.

5. Die Burger, 3 June 1981.

6. Burton, J.C.: CB Winds of Change (Defence and Foreign Affairs, No 7, 1980).
7. Chapman, B.: Chemical Warfare: The Dirty Weapon (National Defence, June 1980).

8. The Citizen, 21 June 1980.

9. The Citizen, 11 April 1981.

10. Cook, C. et al: The Atlas of Modern Warfare, London, 1978.

11. Cookson, J. et al: A Survey of Chemical and Biological Warfare, London (etc), 1969.

12. Dick, C.J.: Soviet Chemical Warfare Capabilities (International Defence Review, № 1, 1981)

13. Eifred, G.: Russian CW: Our Archilles Heel, Europe (Army, December, 1979).

14. Foreign Report, 2 July 1980

15. Ground Defence International, No 62, March 1980

16. Ground Defence International, No 63, April 1980.

17. Harvey, D.: Fighting the Chemical Fight (Defence and Foreign Affairs, No 7, 1980).

18. ISSUP Strategic Review, September 1979.

19. ISSUP Strategic Review, August 1980.

20. Meselson, M. et al: Chemical Warfare and Chemical Disarmament (Scientific American, No 4, April 1980).

21. The Star, 10 October 1980.

22. Raymond, N.V.: Is USAF Ready for Chemical Warfare 7 (Air Froce Magazine, November 1979).

23. Walton, J.: Running the Gas Gauntlet (Soldier, Vol XXXVI, № 8).

24. Watkins, T.F.: Chemical Warfare, Pyrotechnics and the Fireworks Industry. Oxford (etc), 1968. 


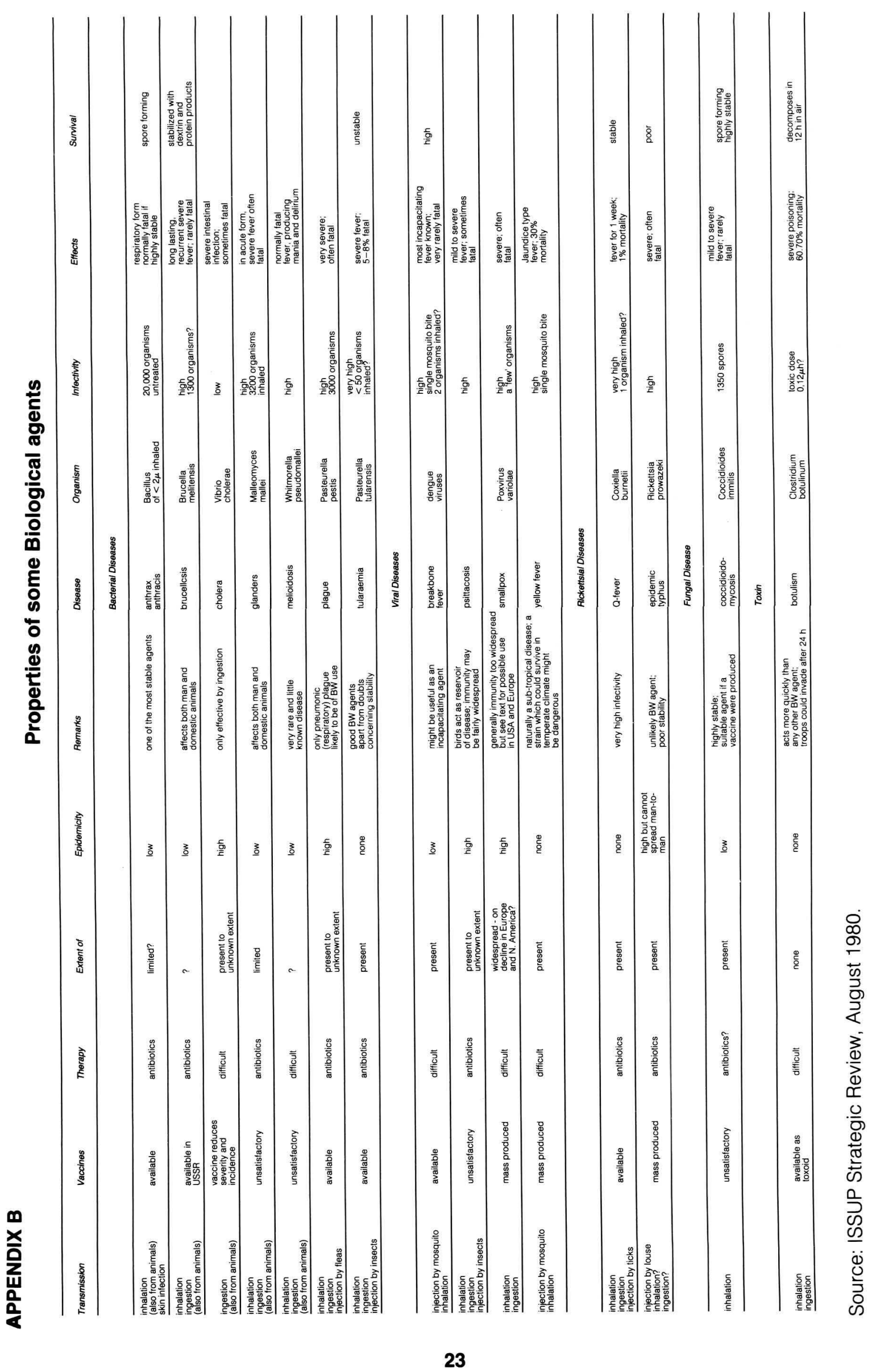




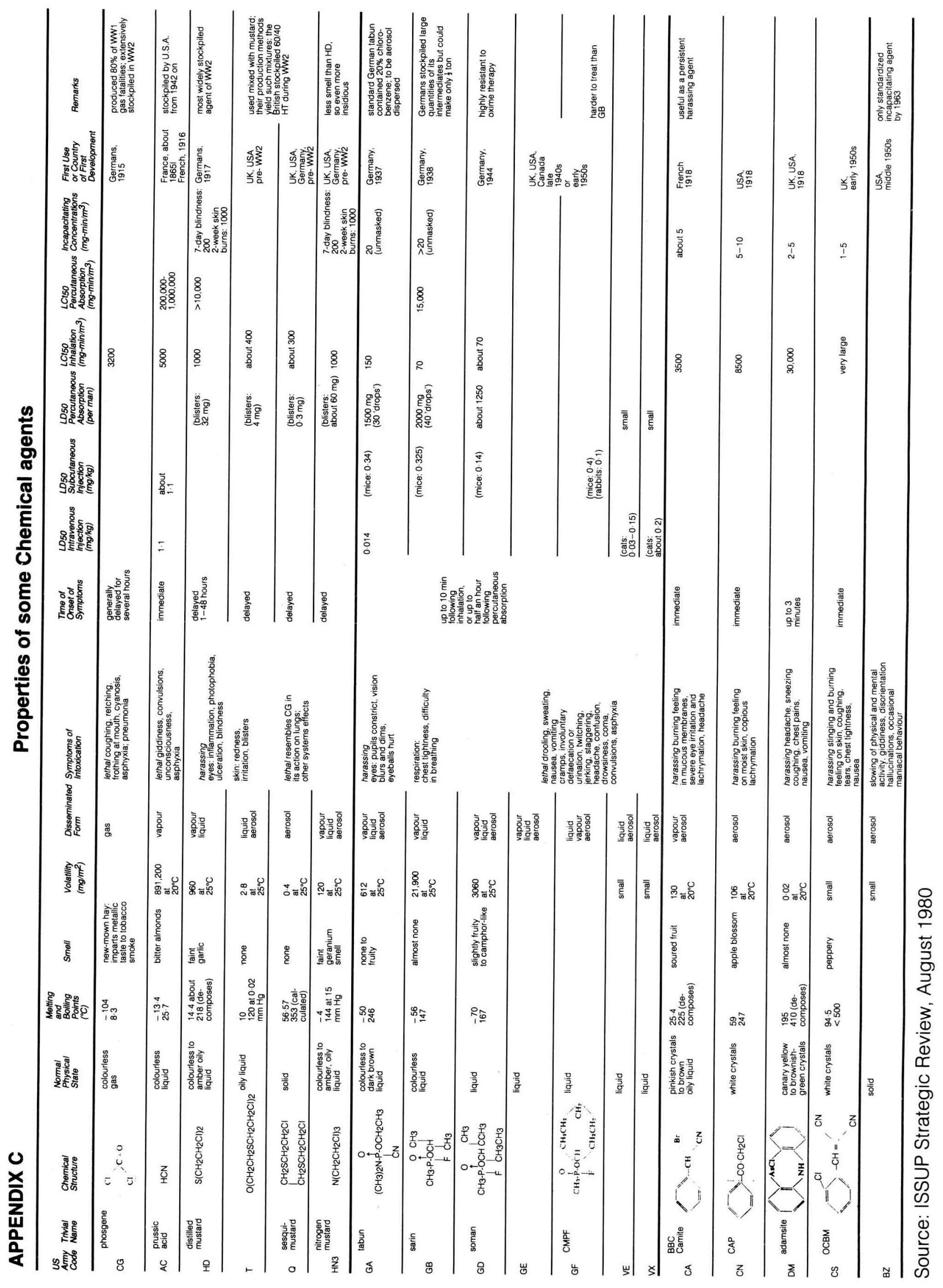




\section{APPENDIX D}

Tactical Missiles and Artillery pieces with CW Capability

1. Tactical Missiles with CW Capability

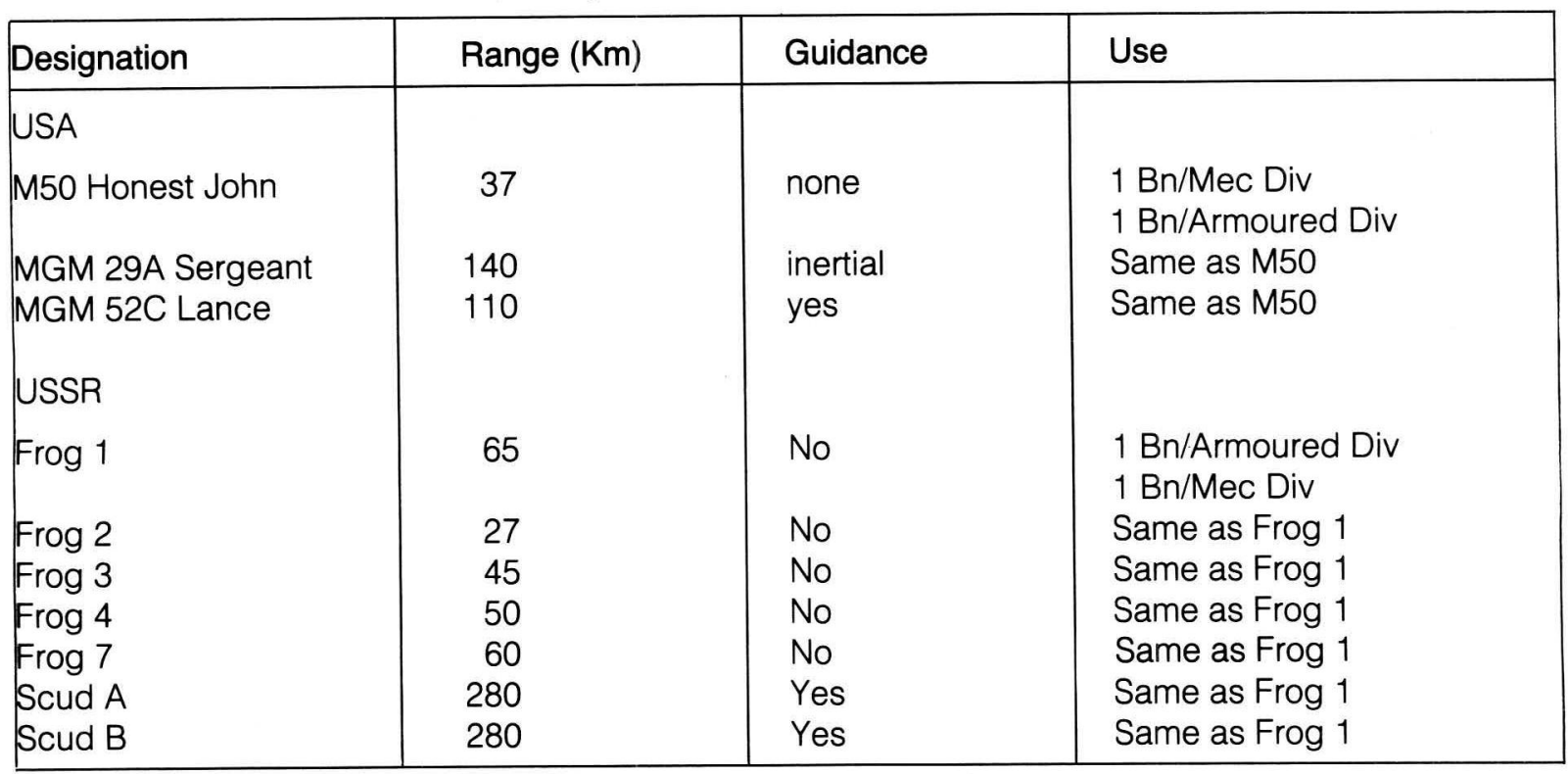

2. Artillery Pieces with CW Capability

\begin{tabular}{|c|c|c|c|c|}
\hline Designation & Type & $\begin{array}{l}\text { Calibre } \\
(\mathrm{mm})\end{array}$ & $\begin{array}{l}\text { Range } \\
(\mathrm{Km})\end{array}$ & Employment \\
\hline \multicolumn{5}{|l|}{ USA } \\
\hline M44 & SP How & 155 & 14,8 & - \\
\hline M52 & SP How & 105 & 11,2 & - \\
\hline MM108 & SP How & 105 & 12 & - \\
\hline M109 & SP How & 155 & 14,6 & 3 Bns/Mec Div \\
\hline M110 A1 & Sp How & 203 & 20,6 & $1 \mathrm{Bn} / \mathrm{Mec} \mathrm{Div}$ \\
\hline M59 & Gun & 155 & 23,5 & - \\
\hline M101 A1 & How & 105 & 11 & 3 Bns/Inf Div \\
\hline M102 & How & 105 & 11,5 & 1 Bn/Airb Div \\
\hline M114 A1 & How & 155 & 14,6 & 2 Bns/Inf Div \\
\hline M115 & How & 203 & 16,9 & 1 Bn/Inf Div \\
\hline XM198 & Gun/How & 155 & 18 & 2 Bns/Mec Div \\
\hline XM204 & How & 105 & - & Experimental \\
\hline \multicolumn{5}{|l|}{ USSR } \\
\hline $\mathrm{D}-20$ & Gun/How & 152 & 18 & 2 Bns/Mec Div \\
\hline M 1938 & How & 122 & 11,8 & 1 Bn/SP Div \\
\hline BM24 & MLR & 140 & 7 & $1 \mathrm{Bn} / \mathrm{Mec} \mathrm{Div}$ \\
\hline \multicolumn{5}{|l|}{ BRITAIN } \\
\hline $26 \mathrm{Pd}$ & Gun/How & 88 & 12,3 & $1 \mathrm{Bn} / \mathrm{lnf} \mathrm{Bde}$ \\
\hline Light Gun & Gun/How & 105 & 15 & - \\
\hline M56 & Gun/How & 105 & 10,6 & Airborne Units \\
\hline
\end{tabular}

Source: Ground Defence International, April 1980. 


\section{APPENDIX E}

\section{US Nerve Gas Weapons}

1. Munitions Charged with GB (sarin, isopropyl methylphosophonofluoridate)

a. Tube and rocket artillery.

b. Infantry weapons (3,5 inch rocket; aerosol generator).

c. Naval ordinance (5 and 6 inch shells).

d. Guided missiles.

e. Aircraft spray tanks (40-100 gallons).

f. Aircraft bombs (500-1 ??? lbs; cluster bombs)
2. Munitions charged with VX (ethyl S-2-diisopropylaminoethyl) methylphosphonothiolate

a. Tube and rocket artillery.

b. Infantry landmine (2 gallons).

c. Naval Ordinance (5 inch shells).

d. Guided missiles (sergeant).

e. Aircraft spray tanks (80-160 gallons).

f. Aircraft bombs (500 lb; cluster bomb).

Source: SIPRI: Chemical Disarmament - New Weapons for Old.

\section{APPENDIX F}

\section{Chemical Warfare Comparison}

\begin{tabular}{|l|l|}
\hline United States & Soviet/Warsaw Pact Nations \\
\hline \multicolumn{2}{|c|}{ Direction Systems } \\
\hline $\begin{array}{l}\text { The M-8, a chemical agent alarm, has been } \\
\text { developed recently. }\end{array}$ & $\begin{array}{l}\text { Battle tanks have automatic detection devices } \\
\text { which close all apertures, and filter air if gas is } \\
\text { detected. }\end{array}$ \\
\hline \multicolumn{2}{|c|}{ Protective Clothing } \\
\hline Suit being developed, not in general use. & $\begin{array}{l}\text { Every Soviet foot soldier has gas mask totally } \\
\text { resistant to chemical agents, carries gloves, } \\
\text { leggings and boots with cape which converts to } \\
\text { overall suit. }\end{array}$ \\
\hline Numbers of Army Chemical Specialists \\
\hline $\begin{array}{l}\text { Chemical Corps. } \\
\text { Chem officers and enlisted men in Army }\end{array}$ & $\begin{array}{l}\text { USSR Army has 80 000 to 100 000 officers and } \\
\text { enlisted men trained in the use of chemical } \\
\text { weapons and self defence measures. }\end{array}$ \\
\hline
\end{tabular}

Source: National Defence, June 1980. 


\section{APPENDIX G}

\section{USSR's Chemical Delivery means}

\begin{tabular}{|c|c|c|c|}
\hline \multicolumn{4}{|l|}{ Division } \\
\hline \multicolumn{4}{|c|}{ Weapon } \\
\hline Designation & $\begin{array}{l}\text { Calibre } \\
\text { Type (mm) }\end{array}$ & $\begin{array}{l}\text { Max range } \\
(\mathrm{m})\end{array}$ & Max rate of fire \\
\hline $\begin{array}{l}M-43 \\
m-74 \\
M-73 \\
B M-21\end{array}$ & $\begin{array}{l}120 \text { Mor } \\
127 \text { How } \\
152 \text { How } \\
122 \text { MRL }\end{array}$ & $\begin{array}{r}5700 \\
15200 \\
17200 \\
20500 \\
\end{array}$ & $\begin{array}{c}12-15 \text { rds per min } \\
6-8 \text { rds per min } \\
7-8 \text { rds per min } \\
40 \text { rds in } 20 \text { secs }\end{array}$ \\
\hline \multicolumn{4}{|l|}{ Army } \\
\hline $\begin{array}{l}\text { D-20/M-73 } \\
M-46 \\
M-77 \\
\text { Scud }\end{array}$ & $\begin{array}{l}155 \text { How } \\
130 \text { Gun } \\
240 \text { MRL } \\
850 \text { SSM }\end{array}$ & $\begin{array}{l}17200 \\
27000 \\
\text { over } \\
30000 \\
280000\end{array}$ & $\begin{array}{l}4 / 7-8 \text { rds per min } \\
5-6 \text { rds per min } \\
\begin{array}{r}- \\
-\end{array}\end{array}$ \\
\hline \multicolumn{4}{|l|}{ Air Force } \\
\hline \multicolumn{4}{|c|}{$\begin{array}{l}\text { The MiG-27 Flogger D, the Su-17 Fitter } \mathrm{C} \text {, and the Su-24 Fencer are the most modern aircraft in } \\
\text { Frontal Aviation's inventory. } \\
\text { They are all capable of delivering } \mathrm{CW} \text { munitions, having maximum payloads ranging between at } \\
\text { least } 2-5 \mathrm{t}(\mathrm{MiG}-27) \text { and } 6 \mathrm{t} \text { or more (Su-24). } \\
\text { With a hi-lo-hi mission profile, they could all make chemical attacks on targets in the west of mainland } \\
\text { Europe. } \\
\text { The Su-24 has sufficient radius of action to reach all major operational areas in the UK. }\end{array}$} \\
\hline
\end{tabular}

Source: International Defence Review: No 1, 1981. 